\title{
Deceptive Utterances Captured in Rian Johnson's Knives Out
}

\section{Ujaran-Ujaran Menipu dalam Film Knives Out Karya Rian Johnson}

\author{
Miftakhul Khoiroh \\ Universitas Negeri Malang, Jl. Semarang No. 5 Malang, Jawa Timur, Indonesia \\ *Penulis korespondensi, Surel: miftakhulkhoiroh2@gmail.com
}

Paper received: 02-09-2021; revised: 14-09-2021; accepted: 25-09-2021

\begin{abstract}
This research aims to analyze the deceptive utterances in a movie entitled Knives Out (2019). Different from previous research, this research does not only focus on one character, but also the other characters who are potentially being deceptive. By doing analysis based on theory of types of deception, this qualitative research analyzed the video of the movie along with the script to solve the research problems regarding how the utterances in the movie can be categorized as deceptive utterances. Moreover, this research also used the theory of deception motive to investigate the relationship between motive and the type of deception employed by the characters. The results show that the movie contains 23 deceptive utterances, and the motive influences the characters in determining what type of deception strategy they should use. This research contributes to the existing knowledge of deception by pointing out that each character uses deception in two different kinds of purposes: deception to achieve their goal, and deception to save them in unfavorable circumstances.
\end{abstract}

Keywords: deceptive utterances, motives, types of deception strategy, Knives Out

\begin{abstract}
Abstrak
Penelitian ini bertujuan untuk menganalisis ujaran-ujaran menipu dalam film berjudul "Knives Out" (2019). Berbeda dengan penelitian sebelumnya, penelitian ini tidak hanya fokus pada satu karakter saja, tetapi juga pada karakter lain yang juga berpotensi menipu. Dengan melakukan analisis berdasarkan teori jenis-jenis penipuan, penelitian kualitatif ini menganalisis video film beserta naskahnya untuk memecahkan masalah penelitian tentang bagaimana ujaran-ujaran dalam film dapat dikategorikan sebagai ujaran-ujaran menipu. Selain itu, penelitian ini juga menggunakan teori motif penipuan untuk menyelidiki hubungan antara motif dan jenis penipuan yang digunakan oleh karakter. Hasil penelitian menunjukkan bahwa film tersebut mengandung 23 ujaran penipuan dan motif mempengaruhi karakter dalam menentukan jenis penipuan apa yang harus mereka terapkan. Secara umum, motif dibagi menjadi dua: penipuan untuk mencapai tujuan mereka, dan penipuan untuk menyelamatkan mereka dalam keadaan yang tidak menguntungkan.
\end{abstract}

Kata kunci: ujaran menipu, motif, jenis strategi penipuan, Knives Out

\section{Introduction}

In general, not all interactions are conducted truthfully. People have various kinds of reasons and causes why they are being deceptive in certain contexts and situations. Hence, people who are being deceptive presumably have certain intentions or motives. People have to confront a situation and minimize the misunderstanding in order to achieve their goals which is one of the ways is by being deceptive (McCornack, 1992), for instance, to have a good image, to cover up faults, to get certain advantages, and so on. However, people might not be able to identify deception properly. People often misinterpret between truth and deception. (Dzindolet \& Pierce, 2005) stated that people need to have the ability of detecting deception since it is a significant skill. Not only guessing, conjecturing, or assuming, but people also need to understand the principle to know the differences between the truth and falsity. The 
linguistics style used is different when people tell the truth and when they are being deceptive (Pennebaker, Mehl, \& Niederhoffer, 2003).

Regarding deceptive utterances and motives, Knives Out is a movie that can help to look deeper into this topic. This movie tells about figuring out the suspect of a murder case. During the interrogation scenes, the deceptive utterances are scattered up. Interestingly, even though the actual suspect is only one person, the other people who are investigated are being deceptive as well (Johnson, 2019). Their motives of being deceptive are appealing to be investigated. The huge number of deceptive utterances in this movie is the reason to conduct research on this movie. Moreover, this movie is chosen since it is considered as a recent movie which was released in 2019 , so that there is still not much research on this movie especially in the area of linguistics. The center point of this study is on the deceptive utterances expressed by some selected characters: Richard Drysdale, Walt Thrombey, Joni Thrombey, Marta Cabrera, and Hugh Ransom Drysdale in the interrogation scenes. The decision for choosing some characters is because the deceptive characters are not only the suspect, so I can compare the deceptive utterances of the suspect and non-suspect.

Research on deception in linguistics has been conducted by some researchers with various research objects and focuses (e.g., Addawood, Badawy, Lerman, \& Ferrara (2019); Francis (2018); Hancock, Curry, Goorha, \& Woodworth (2008); Levitan, Maredia, \& Hirschberg (2018); Makhfiana \& Himmawati (2017); Merzah \& Abbas (2020); Newman, Pennebaker, Berry, \& Richards (2003), Nugrahaeni (2019), Picornell (2013), and Wangru, (2016)). The researchers examined deception in movies, various kinds of text data, social media, and spoken data like an interview. Deception can be found in movies as captured in characters' utterances by employing various deception strategies (Makhfiana \& Himmawati, 2017; Nugrahaeni, 2019). In the form of text, analysis on deception has been done in novel, text-based setting, and text written by a witness (Hancock et al., 2008; Merzah \& Abbas, 2020; Newman et al., 2003; Picornell, 2013). In the age of technology, social media can be a medium of deception. Social media as a platform where information can be spread quickly is such a nest for uncredible and less evidence information which is manifested in fake news (Francis, 2018). Meanwhile, in spoken data, deception is analyzed in dialogue of interview and cognitive interaction (Levitan et al., 2018; Wangru, 2016).

Previous research, especially the research on movies, mostly tend to focus on deceptive utterances spoken by the suspect (one person) only. This research, however, selected several characters who are also potentially being deceptive as the focal point of the investigation. It will bring new insight where I can compare the differences between the deceptive utterances of the suspect and the non-suspect. Therefore, this research prominently identifies how the utterances spoken by selected characters in Knives Out movie can be considered as deceptive utterances. Pragmatics theory about types of deception is used. This research is also intended to enrich knowledge by examining the relationship between the deception motives and the strategy used. The research is expected to be beneficial for people especially English students in identifying deceptive utterances in movies by examining the linguistics strategy.

Deception is such a trick of manipulation to tell something which is not in accordance with reality (Druckman \& Bjork, 1991). Prominently, there are two basic tricks in deception which are concealment and falsification (McCornnack, 1992). When people conceal, they do not say the whole information, but they tend to uphold the important information. Meanwhile, 
when people falsify, they tell the wrong information as the truth (McCornack, 1992). This pragmatics theory is functioned to determine the deception category of the utterances in this movie. Since this theory explains the way the characters tell deception, I can also see the strategy of the characters in the movie when telling deception.

There are two types of deception including dissimulation and simulation (Bell \& Whaley, 2017). Dissimulation (hiding) is described as a type of deception in which the way the person tells the untruthful things by hiding or withholding the information. Dissimulation is divided into three strategies: 1) masking is done by blending the truth with the background pattern. Masking really depends on the surroundings or the situation; 2) repackaging, in repackaging, the truth is wrapped and modified in diverse ways. It can be by adding irrelevant information or even by doing something dangerous; 3 ) dazzling, the interlocutor knows the truth, but dazzling enables the speaker to distract the interlocutor to be confused hence the truth becomes blurred. Differently, a deception can be categorized as simulation (showing) when a person tries to tell wrong or even misleading information. Similar to dissimulation, simulation also has three strategies: 1) mimicking is showing the false by copying a certain character as if it is a truth. It is done not only to hide the truth but also to achieve a goal; 2) inventing is applied when mimicking and hiding is not possible to cover up the truth. It is done by creating new patterns that actually do not exist; 3) decoying enables deceivers to manipulate the interlocutor by attracting and pursuing with the high tension of certainty. Furthermore, Merzah and Abbas (2020) compiled some types of deception from several researchers such as Dynel (2018), Fallis (2010), Galasiński (2000), Schröter (2013), and Vincent and Castelfranchi (1981). The researchers classified them into withholding information, equivocation, red herring, and lying. Withholding information is a type of deception which leads the interlocutor to believe in an untrue fact. It is divided into two: half-truths and silence (Dynel, 2018). The second is equivocation. This kind of deception is well known with the use of manipulative language which also sometimes apply euphemism and/or dysphemism (Vincent \& Castelfranchi, 1981). According to (Allan \& Burridge, 2006), euphemism is shortly known as sweet talking means the speaker makes something have a good and positive image. Fear and hatred are the common triggers of euphemism. Meanwhile, dysphemism as the opposite of euphemism is offensive talking. The speaker tries to degrade something/someone since the speaker thinks it disturbs him. Equivocation is a form of violation of maxim of manner since the speaker seems vague and ambiguous (McCornack, 1992). Meanwhile, red herring consists of two strategies: evasion and distraction. Evasion itself is a form of the violation of maxim of relevance and quantity (Galasiński, 2000). Meanwhile in distraction, (Schröter, 2013) explained that in order to achieve his goal, the speaker usually attempts to switch one topic to another, and even attacks the interlocutor. It is commonly marked by impoliteness strategy and flouting maxim of relevance and/or quantity (Merzah \& Abbas, 2020). The last is lying. Lying is actually under classification of deception. As we all know that lying is a deception strategy where the speaker attempts to convince the interlocutor about something wrong to be right or the vice versa (Fallis, 2010). (Merzah \& Abbas, 2020) added that flouting maxim of quality can be seen through this type of deception since in lying, the speaker tries to assure the interlocutor with the untruth information.

Motive is such a cornerstone in deception. The deception strategy employed is affiliated to the motive. As explained that in determining what deception strategy should employ, deceiver will take consideration over the motive (Utz, 2005). The strategy used by deceivers means something to the deceiver's motive, for instance, (Joinson \& Dietz-Uhler, 2002) in their 
study mentioned identity play as one of deception motives on the internet. This kind of motive leads people to be deceptive by giving invalid personal information and tend to be anonymous. In other words, motive leads the deceiver to determine and choose what suitable deception strategy to cover up their deception. The suitable type of deception strategy for this case can be withholding information and/or simulation (inventing) where the deceiver can cover up or even create his new personal data.

\section{Method}

This research is descriptive qualitative research which deals with descriptive analysis. This method suits the aim of this research which refers to interpreting meaning and context rather than number. The data were collected from a movie entitled Knives Out (2019), the video of the movie along with the script. The use of the script is considered to assist me in analyzing the utterances. The data analysis steps were developed based on the necessity of the research. Those steps are: first, watching the whole part of the 2 hours and 10 minutes long movie to get to know the whole story of the movie and understand the context; second, selecting the focus of the scenes and characters to narrow down the scope of the analysis; third, grouping the utterances based on the type of deception strategies; fourth, the main step, analyzing the utterances by applying the theories; last, withdrawing conclusions based on the results of the research

\section{Results and Discussion}

\subsection{Types of Deception in Knives Out (2019)}

The first section aimed for the first research problem regarding how the utterances in the movie are considered as deception. The data is focused only in the interrogation scenes. In order to examine the utterances, I applied theory of types of deception from several experts. The utterances are explained as follows.

Table 1. Frequency of Types of Deception Strategy

\begin{tabular}{clc}
\hline No. & \multicolumn{1}{c}{ Types of Deception } & Total \\
\hline 1. & Dissimulation & \\
& - Masking & 0 \\
& - Repackaging & 0 \\
& - Dazzling & 0 \\
2. & Simulation & \\
& - Mimicking & 0 \\
& - Inventing & 1 \\
& - Decoying & 2 \\
3. & Withholding Information & 3 \\
4. & Equivocation & \\
& - Euphemism & 3 \\
5. - Dysphemism & 3 \\
& Red Herring & \\
& - Evasion & 4 \\
6. Distraction & Lying & 6 \\
\hline & & 26 \\
\hline
\end{tabular}

Based on the table above, the most used type of deceptive strategy is red herring (distraction). The characters use this strategy when they feel cornered during the interrogation. By using this strategy, they can distract the interlocutors' attention by shifting 
the topic, so that they can escape from the unfavorable circumstances, for instance when the cops and the detective accuse them. Meanwhile, dissimulation is not used by any characters in this movie. There are 3 utterances that apply 2 types of deception strategy in one utterance. That is why even though the amount of the deceptive utterances is 23 , the total number in the table is 26 .

\section{Simulation}

As explained in the Introduction Section, in simulation, the deceiver tries to give misleading information to the interlocutor (Bell \& Whaley, 2017).

\section{a. Inventing}

The way inventing manipulates the interlocutor is by creating new things or stories that actually do not even exist (Bell \& Whaley, 2017).

\section{Richard: "Yes. I know - yes, ha [U-7a]. So, Harlan decided to finally put his mom in a nursing home. Which Linda always opposed. And I was going to wait till we were back home in Boston to tell her, so there wouldn't be a whole scene, but Harlan wanted me to tell her then [U- 7b]. That was it. Sorry. Forgot." (Johnson, 2018, p. 20).}

The cited utterance is in the middle of the interrogation of Richard Drysale. Detective Blanc asks and attempts to push him about whose man scream voice belongs to at that time. In the end, admits that it is his voice by answering as in [U-7a]. In the utterance, he mentioned "yes" twice shows that he feels cornered and forced to admit it at that time. Even though he has admitted, he still hides another fact about the cause he had a dispute with Harlan. Instead of telling the truth, Richard creates a new story regarding what happened between him and Harlan that night as captured in [U-7b]. Meanwhile, what actually happened is that both Richard and Harlan were bickering about Richard's infidelity and Harlan warned him that he was going to tell Linda, Richard's wife, about it. This is what is called as simulation (inventing) where the deceiver tells the interlocutor about the new story s/he creates which is in contradiction with the fact to cover up the truth (Bell \& Whaley, 2017). Furthermore, he mentioned "that was it" as a sign to restrict the conversation and prohibit the detective from asking more regarding this topic.

\section{b. Decoying}

Decoying is able to manipulate the interlocutors by pursuing them with the high level of certainty of wrong fact (Bell \& Whaley, 2017).

Marta: "I took him upstairs. We played our nightly game of GO, at some point he knocked the board over and Joni came up to check on us. Then I gave him pain medication, he pulled his shoulder last week, and left him in his study. At midnight. Said bye to Walt went home." [U-18]

L. Elliott: "What medication did he get?"

Marta: $\quad$ "Since his injury I've been giving him a 100 milligram IV push of Toradol, a non narcotic analgesic. And to help him sleep, 3 milligrams of morphine." [U-19] (Johnson, 2018, p. 46).

Detective Blanc starts the interrogation with Harlan's nurse, Marta Cabrera. She is asked about what happened that night after Harlan's birthday party was over. Marta answers it and tells the whole thing she did with Harlan until she left the house. 
Marta deliberates all her activities with Harlan as stated in [U-18] and [U-19]. This statement seems true, yet if I take a look at the details, she misses some things and intends to omit it. It is in the part after she gave medication, she states that she directly came home. Meanwhile, the time after she gave medication and before she went home is the main point where the tragedy occured. It was the time where she accidentally gave the wrong medication to Harlan and how she did all of Harlan's plans to cover up the accident. As mentioned, she does attempt to omit that point here. Fortunately, Marta is able to tell it in order and smoothly like Harlan's command, so that her statements do not feel suspicious at all. Considering the compatibility of the time and the activity informed between Marta and Thrombeys, all of her statements can be accepted, makes sense, and considered to have a high level of accuracy as how decoying should be (Bell \& Whaley, 2017).

2. Withholding information

As previously mentioned, withholding information provokes the interlocutor to believe in an untruth fact by mentioning half truth (Dynel, 2018).

$$
\begin{aligned}
& \text { Joni: "It was just a mix up with the payment for Meg's tuition." [U-16] } \\
& \text { Blanc: "I'm sorry to press, what kind of mix up?" } \\
& \text { Joni: } \quad \text { "Just a money wiring issue. With the office at the school. So I had to } \\
& \text { ask Harlan to cut a check for this semester. No big deal." [U-17] } \\
& \text { (Johnson, 2018, pp. 21-22). }
\end{aligned}
$$

Joni is interrogated by Detective Blanc regarding why she came early and what she did on the day of Harlan's birthday party. Detective Blanc knows that she was having a dispute with Harlan and he asks for confirmation from her. Joni indirectly admits it and tells them what is going on at that time.

In [U-16], Joni mentions "just a mix up" as if it is not a big trouble, while the truth says it is not just a mix up, but a big problem where she manipulates her daughter's tuition fee to get more allowance from Harlan. In order to get more exact statements, Detective Blanc keeps asking what exactly the mix up is about. Joni reveals the half truth that it is about her daughter's tuition as mentioned in [U-17], but she does not reveal what the cause of the problem is, that she is the one who manipulates the allowance. In this utterance, she mentioned "just money wiring issue", and "no big deal". The word "just" and the rest of the sentence is the way she portrays the problem as if it is not a serious problem. It includes her tricks in revealing the half truth. Thus, [U-16] and [U-17] are considered as withholding information since in withholding information, the deceiver only reveals half-truth, yet still hides the other truth (Dynel, 2018).

\section{Equivocation}

Equivocation employs manipulative language by using euphemism and/or dysphemism (Vincent \& Castelfranchi, 1981).

\section{a. Euphemism}

Euphemism is also known as sweet talking means the speaker attempts to create a good/positive image of an object she/he talks about (Allan \& Burridge, 2006).

$$
\begin{aligned}
\text { Richard: “...But my wife, Linda does. Harlan started with a rusty Smith } \\
\text { Corona, built himself into one of the bestselling mystery writers of } \\
\text { all time." }{ }^{[\mathrm{U}-1]} \text { (Johnson, 2018, p. 8). }
\end{aligned}
$$


The utterances is Richard's response toward Lieutenant Elliott's previous statement. In this conversation, Richard is talking about the positive image of Linda (his wife) and also Harlan (his father-in-law). He seems to admire Linda and Harlan so much by mentioning how Linda respects and loves her father so much, and how great Harlan who is very successful in building his career [U-1]. Through the word "rusty", Richard wants to say how great Harlan is in creating masterpieces from the old typewriter. He also mentioned "all time". Both phrases aim to exaggerate Harlan's skill and career as a novel writer (hyperbole). The utterance violates the maxim of manner since it is really ambiguous. Richard himself is the one who bring this kind of topic to show that his relationship with both Linda and Harlan is fine while the truth is the vice versa. He had a dispute with Harlan because Harlan knows that Richard is having an affair with another woman. He applies this strategy because he was triggered by fear of being divorced by his wife Linda. Creating something becomes good as what Richard employs in this conversation is named as equivocation (euphemism) strategy (Allan \& Burridge, 2006).

b. Dysphemism

Meanwhile, dysphemism is the opposite of euphemism. Dysphemism is an offensive talking which leads the speaker to create the negative side of an object (Allan \& Burridge, 2006).

Walt: $\quad$ "But he's always been the black sheep of the family [U-13a], and I'm not, I, keep stuff like this in the family, but with Ransom, he's never had a job [U-13b]. But dad for some unknown reason has always supported him[U-13c], they've got this love hate bond. They fight. But that night, God. They had blown out."

Blanc: "About what?"

Walt: $\quad$ "We couldn't make it out, but it was huge. And it was strange they went in another room to do it they usually love stoking up drama in front of the whole family." [U-14] (Johnson, 2018, p. 18).

After Walt is interrogated regarding the dispute between him and Harlan that night, he decides to disclaim that he was having a quarrel. Then, he directly switches the topic to Ransom. That is how this conversation between him and Detective Blanc occurs. The detective seems welcomed to it and gives a chance to him to continue to talk about Ransom.

Walt shows his feeling of hatred toward Ransom through the above statement. In [U13a], Ransom is described as a "Black sheep in the family" which means he is such a disgrace of the family. Furthermore, in [U-13b], Walt says that Ransom is an unemployed person. From these two phrases, it can be concluded that Ransom is such a troublemaker in the family with no job and all of the problems he makes. Then, proceed to [U-14] where Walt tells how the dispute between Ransom and Harlan takes place. Walt said "it was huge" to emphasize and exaggerate the dispute (hyperbole).

All of the utterances that Walt says referring to Ransom have negative connotations just the same as the definition of dysphemism (Allan \& Burridge, 2006). Even though what Walt says is a fact, it is very impossible that he carries out this strategy for no reason. Considering how the situation he is in at that time, that is being cornered by the questions he receives during the interrogation, it is highly possible if he intends to get advantage by doing that. Walt thinks that by shifting the topic and talking about how bad Ransom is, it will distract the focus and attention of the detective and the cops hence they will have suspicion or even accusation 
toward Ransom instead of him. Moreover, it is also caused by his jealousy toward Ransom as in [U-13c]. It seems ambiguous how Walt brings this topic and shows his feelings of hatred of Walt toward Ransom which make these utterances violate the maxim of manner.

\section{Red herring}

In covering the truth, red herring employs two strategies which are evasion and distraction (Merzah \& Abbas, 2020).

a. Evasion

Same as the name, evasion allows the interlocutors to be evasive when they are asked or interrogated. The evasive utterances can also be categorized as a violation of maxim of relevance and quantity (Galasiński, 2000). Walt: "What? Richard said what? Jesus. No, we didn't get "into it"."
[U-9] (Johnson, 2018, p. 16).

Detective Blanc tells Walt about what Richard said about him and Harlan at the night of the birthday party. That he had a fight with Harlan talking about the movie adaptation. Blanc asks for confirmation from Walter whether it is true or not and Walt denies it.

As a response toward an accusation from Blanc, Walter says as cited in utterance [U-9]. He straightly and evasively states that the accusation is not true. Still about utterance [U-9], he mentions the word "Jesus" in the middle of his evasion statement as if he swore in the name of God. This word is aimed to convince the interlocutor to believe his statement. Moreover, his answer is considered as a violation of maxim of quantity since his information is too much as required (Galasiński, 2000). This evasive response can be defined as a manifestation of evasion.

\section{b. Distraction}

Speakers can be categorized employing distraction when they attempt to switch the topic of conversation and even attack the interlocutors when they feel cornered. It is a form of flouting maxim of relevance and/or quantity (Schröter, 2013).

Ransom: "You have her confession!"[U-22] (Johnson, 2018, p. 112).

The context is in the interrogation of Ransom. Detective Blanc is putting Ransom in a hard position by revealing more truth. At this point, Ransom switches the talk by mentioning that Marta has confessed the murder with the consideration it will save him from the accusation as the suspect. The strategy he uses is called as red herring (distraction), where deceiver attempts to switch the focused topic to another (Schröter, 2013). Impoliteness strategy also can find in this conversation in a form of interruption since this utterance is shouted by Ransom to cut off Detective Blanc's talk.

\section{Lying}

People who are lying have an intention to convince the interlocutor by providing wrong information hence lying is a form of flouting of maxim of quality (Fallis, 2010).

Walt: "Look, we love Ransom, he is a good kid, we love him." [u-11] (Johnson, 2018, p. 18).

This utterance is stated by Walt in the middle of conversation with Detective Blanc when he successfully shifts the topic during his interrogation. At first, it is seemingly clear that he has 
feeling of hatred toward Ransom. Thus, this sentence can be assumed is not intended to employ the actual meaning, but it has another hidden meaning. Through this sentence, Walt as if wants to convey that he hates Ransom, he is not a good kid or in other words, the meaning delivers the opposite meaning (Fallis, 2010). In other words, this utterance is sarcasm as how violation of maxim of quality should be.

From those various types of deception strategies, simulation (decoying) and withholding information are the strategies that are quite effective. Based on the previous explanation, those two types of strategy can successfully manipulate the interlocutors to believe in the deceiver's statements as happen to Marta Cabrera in [U-18] and [U-19]. When she is asked about what she did with Harlan at the night when the incident occurred, she is able to tell the whole story smoothly without making the interlocutors realize that she has actually omitted the main tragedy.

Based on the explanation above, types of deception strategy used by the characters are varied. Each character uses more than one types of strategy. In addition, by looking at the context and the diction in characters' utterances, I could reveal what types of deception the characters used. The findings of the current study are similar to the study conducted by Merzah and Abbas (2020). However, their research has only been carried out in a small number of types of deception strategy. This current research found more various types of strategies because the scope of the data is wider than Merzah and Abbas' (2020). There are 5 strategies along with the sub-strategies. Moreover, this current research focuses on 5 characters, while Merzah and Abbas' (2020) only used one character as the research focus. With those 5 characters with different characteristics certainly make the findings of the current research are more diverse.

\subsection{The Relationship of Motives and The Deception Strategy}

The next section discusses the second research problem regarding the relationship between the motives and the deception strategy. First of all, the explanation starts to reveal the deception motives of the characters. As mentioned, this research focuses on 5 characters: Richard Drysdale, Walt Thrombey, Joni Thrombey, Marta Cabrera, and Hugh Ransom Drysdale. The first is Richard. He covers his quarrel with Harlan that night because it is related to his affair. He threatens Harlan not to tell his wife, Linda about it. He is afraid of being divorced by his wife since if he is divorced, he will not get the inheritance. Secondly, Walt is being deceptive when he talks about the fight with Harlan because it is about Harlan's book company he runs. He presses Harlan to approve the book adaptation, but Harlan firmly rejects it. Because of this, he is fired. If he does not hide this incident, he is worried what if he will not inherit the company and probably the cops and detective will accuse him over the death of Harlan even though the fact says he did not. Thirdly, Joni has a serious talk with Harlan about the monthly allowance for her daughter. Harlan finds out that Joni has been stealing the money by making double reports. Harlan decides to discontinue giving the allowance. Again, it was about money. The fourth, Marta Cabrera who is Harlan's nurse. She thinks she is the suspect over the death of Harlan for giving wrong medical treatment. Therefore, her utterances during the interrogation scene also contain deception. She tells about what she did with Harlan at the night of the incident by omitting the detail and main event. The last is Ransom, the actual suspect. He is the one who traps Marta as if she is the suspect. Even though the circumstances and the accusation are referring to him, he still defends himself and denies it. He does all of that since he knows well that all of his inheritance will be given to Marta. 
According to Utz (2005), the type of strategy chosen by deceiver is determined by the motive, for instance, deception which is commonly found in the internet mostly related to identity play (Joinson \& Dietz-Uhler, 2002). The deceiver does this usually to cover up the actual identity. With this kind of motive, it really makes sense for the deceiver to choose simulation (inventing) as the strategy.

Bringing this theory to this research, First, Richard, who has the motive to cover up his affair, applies the equivocation (euphemism) strategy when talking about his wife and fatherin-law. This is intended to make him seem like to create an image that his relationship with his wife and father-in-law is fine; equivocation (dysphemism) used when he talked about other family members. In accordance to the inheritance, probably he assumes his other Thrombeys as his villain in getting the heritance; red herring (evasion) applied when he responds to the accusation; he used red herring (distraction) when he feels cornered by the accusations toward him, so he tries to distract the cops and detective's focus by talking about and blaming other family members; and simulation (invention), when he is unable to dodge the accusation, he is forced to tell a story, but adds with "spices" to create a new story that do not actually exist.

The second is Walt. His motive for being deceptive is that he wants to take over his father's book company. The deception strategies he uses are: 1) equivocation (euphemism), when he talks about his father. He does it to create a good image about his relationship with his father; 2) red herring (evasion) applied when he is accused of having quarreled with his father because of an unapproved book adaptation and he denies it with this strategy; 3 ) withholding information, when he is asked about the cause of his fight with Harlan, he only reveals the half part of it and he does not say if it is about a novel adaptation; 4) when he is cornered, he tries to distract the interlocutor by applying red herring distraction. In the movie, he distracts the interlocutor by talking about Ransom; 5) when talking about Ransom, he is lying by saying that he loves Ransom, but these words are intended to employ the opposite meaning of it.

Thirdly, Joni, who has a deception motive due to the fact that she steals her daughter's allowance, exposes 3 types of deception. She applies withholding information when she is asked about the cause of her fight with Harlan. When she is asked about how close her relationship is to Harlan's family, she applies equivocation (euphemism) and lying. Euphemism to create a harmonious relationship between himself and Thrombeys and lying, which seems to state if her statement is completely the opposite or not true.

Fourth, Marta was being deceptive with motive that she thinks she is the one who killed Harlan applies 2 types of deception, namely decoying which used to convince the cops and the detective with a story she tells with a high level of accuracy, and with holding information when she tells about the main tragedy that night by revealing the half-truth and hide the rest other.

The last one is Ransom, the actual suspect in this case. When he is interrogated and accused of being the mastermind over the Harlan's death, he dodges and applies red herring (evasion), and in a state of distress and cornered, he threatens the detective as well as Marta with profanity and insults that can be categorized as red herring (distraction). 
Table 2. Number Strategies Use by The Characters

\begin{tabular}{clc}
\hline No. & \multicolumn{1}{c}{ Characters } & Total of Strategy \\
\hline 1. & Richard Drysdale & 5 \\
2. & Walt Thrombey & 5 \\
3. & Joni Thrombey & 3 \\
4. & Marta Cabrera & 2 \\
5. & Hugh Ransom Drysdale & 2 \\
\hline & Total & 12 \\
\hline
\end{tabular}

The table above is provided to explain the difference of the deception strategy used by the suspect and the non-suspect. The difference between both can be seen through the amount of times they speak and also the number of strategies they use. The amount of times they speak can be seen in the script or the video of the movie during the interrogation scene. The table shows that Richard and Walt have the highest number. Both of them also found out as the characters who talk too much during the interrogation scene. The investigation stated that they are not the suspect. Meanwhile, Ransom, who is the suspect, is found out as the character with the least amount of speaking. Furthermore, looking at the amount of deception strategy, Ransom along with Marta have the same number as stated in table above. It can be assumed that the suspect character tends to be silent and does not speak often. However, it turns out to become confusing since Marta, a non-suspect character, also has the same number of strategies as Ransom. It is because in the beginning, Marta is trapped by Ransom that makes her think that she is the suspect, so she acts like she is the real suspect by controlling his verbal and do not speak often.

Consistent with the previous research, the motive behind deception is triggered by pressure (Nugrahaeni, 2019). Based on the findings above, all of the 5 characters are pressured by the questions asked by the detective and the cops hence it leads them to be deceptive. In addition, too little attention has been paid to the relationship of the motive and the deception strategy. The previous research only investigated how various type of motives lead the character to be deceptive (Nugrahaeni, 2019). This research shows how motive can determine what type of deception strategy they should use. Moreover, since most of previous research on fictional products focus only on one character, their research lacks discussion about the comparison between the deceptive utterances of the suspect and non-suspect which is discussed in this research (Makhfiana \& Himmawati, 2017; Merzah \& Abbas, 2020; Nugrahaeni, 2019).

\section{Conclusions}

The main goal of this research was first, to investigate how utterances in Knives Out can be defined as deceptive utterances, and second to analyze the relationship between motive and deception strategy. Based on the result, I found out that there are 23 deceptive utterances in the movie which are separated into various types of deception strategy.

This current research shows that the motives are owned by the characters, except Marta. It can be assumed that all of the deceptive utterances in the movie are due to Harlan's inheritance. When each of the characters, again, except Marta, talk about other family members, they tend to use the equivocation strategy (dysphemism) because they consider the other family members as rivals in gaining the inheritance, so they hate each other and demonize them. However, when they are talking about Harlan, they implement equivocation (euphemism) because Harlan is the owner of the inheritance hence, they need to show if they 
have a harmonious relationship with him. Regarding the murder case, dysphemism also used to blame the others, and euphemism employed to avoid any accusation about the murder. Thus, in general, deception portrayed in this movie basically is triggered by motives which are divided into two: deception to achieve their goal, and deception to save them in unfavorable circumstances.

The findings of this research contribute to enhance the knowledge regarding the difference of deceptive utterances of the suspect and non-suspect characters. Considering the previous research which mostly look at one character, this research focuses on 5 characters to see the differences which has not been discussed before. Focusing on one character only give limitation to the researcher to compare and look deeper to the other characters. By comparing these two kinds of characters I can see some significant differences in terms of the number of types of deception and the strategy they used.

\section{References}

Addawood, A., Badawy, A., Lerman, K., \& Ferrara, E. (2019). Linguistic cues to deception: Identifying political trolls on social media. Thirteenth International AAAI Conference on Web and social media, 13, 15-25.

Allan, K., \& Burridge, K. (2006). Forbidden words: Taboo and the censoring of language. Cambridge, UK; New York: Cambridge University Press.

Bell, J.B., \& Whaley, B. (2017). Cheating and deception. New Brunswick, N.J: Routledge.

Druckman, D., \& Bjork, R.A. (Eds.). (1991). In the mind's eye: Enhancing human performance. Washington, D.C.: National Academy Press.

Dynel, M. (2018). Irony, deception and humour: Seeking the truth about overt and covert untruthfulness. Boston Berlin: Walter de Gruyter.

Dzindolet, M.T., \& Pierce, L.G. (2005). Using a linguistic analysis tool to detect deception. Proceedings of the Human Factors and Ergonomics Society Annual Meeting, 49(3), 563-567. doi:10.1177/154193120504900374

Fallis, D. (2010). Lying and deception. Philosophers' Imprint, 10(11), 1-22.

Francis, E. (2018). MisInfoWars: A linguistic analysis of deceptive and credible news (Master's thesis, Simon Fraser University, Canada). Retrieved from http://summit.sfu.ca/item/18571

Galasiński, D. (2000). The language of deception: A discourse analytical study. Thousand Oaks, Calif: Sage Publications.

Hancock, J.T., Curry, L.E., Goorha, S., \& Woodworth, M. (2008). On lying and being lied to: A linguistic analysis of deception in computer-mediated communication. Discourse Processes, 45(1), 1-23. doi:10.1080/01638530701739181

Johnson, R. (2018). Knives Out [Screen script]. Retrieved from https://lionsgate.brightspotcdn.com/fb/14/23cd58a147afbb5c758ecb3dff0a/knivesout-final.pdf

Johnson, R. (Director). (2019). Knives Out. [Film]. T-Street Productions.

Joinson, A.N., \& Dietz-Uhler, B. (2002). Explanations for the perpetration of and reactions to deception in a virtual community. Social Science Computer Review, 20(3), 275-289. doi:10.1177/08939302020003005

Levitan, S.I., Maredia, A., \& Hirschberg, J. (2018). Linguistic cues to deception and perceived deception in interview dialogues. Proceedings of the 2018 Conference of the North American Chapter of the Association for Computational Linguistics: Human Language Technologies, Volume 1 (Long Papers), 1941-1950. New Orleans, Louisiana: Association for Computational Linguistics. doi:10.18653/v1/N18-1176

Makhfiana, L., \& Himmawati, D.R. (2017). Deception analysis of Chutney Windham in Legally Blonde movie. Language Horizon, 5(1), 66-73. $\quad$ Retrieved from https://jurnalmahasiswa.unesa.ac.id/index.php/language-horizon/article/view/19178 
McCornack, S.A. (1992). Information manipulation theory. Communication Monographs, 59(1), 1-16. doi:10.1080/03637759209376245

Merzah, S.K., \& Abbas, N.F. (2020). Deception in Flynn's psychological thriller Gone Girl (2012): A pragmastylistic analysis. European Journal of Literature, Language and Linguistics Studies, 3(4), 118-148. doi:10.5281/ZENOD0.3766515

Newman, M.L., Pennebaker, J.W., Berry, D.S., \& Richards, J.M. (2003). Lying words: Predicting deception from linguistic styles. Personality and Social Psychology Bulletin, 29(5), 665-675. doi:10.1177/0146167203029005010

Nugrahaeni, Q.W. (2019). A study of deception in Red Sparrow movie 2018 (Master's thesis, Muhammadiyah University of Surakarta). Retrieved from http://eprints.ums.ac.id/70553/

Pennebaker, J.W., Mehl, M.R., \& Niederhoffer, K.G. (2003). Psychological aspects of natural language use: Our words, our selves. Annual Review of Psychology, 54(1), 547-577. doi: 10.1146/annurev.psych.54.101601.145041

Picornell, I. (2013). Analysing deception in written witness statements. Linguistic Evidence in Security, Law and Intelligence, 1(1), 41-50. doi:10.5195/LESLI.2013.2

Schröter, M. (2013). Silence and concealment in political discourse. Amsterdam/Philadelphia: John Benjamins Publishing Company.

Utz, S. (2005). Types of deception and underlying motivation: What people think. Social Science Computer Review, 23(1), 49-56. doi:10.1177/0894439304271534

Vincent, J.M., \& Castelfranchi, C. (1981). On the art of deception: How to lie while saying the truth. In H. Parret, M. Sbisà, \& J. Verschueren (Eds.), Studies in Language Companion Series (vol. 7, pp. 749-777). Amsterdam: John Benjamins Publishing Company. doi: 10.1075/slcs.7.39vin

Wangru, C. (2016). On deception from the perspective of sociolinguistics. Studies in Literature and Language, 12(5), 54-59. doi:10.3968/8443 